\title{
Federal Court in Texas rules Affordable Care Act unconstitutional
}

\author{
Gilbert Berdine MD
}

On Friday, December 14, 2018, Judge Reed C. O'Connor ruled on a challenge to the Affordable Care Act (ACA) in a federal district court in Texas. National Public Radio published a summary of the court ruling, and the text of the ruling is available online., ${ }^{1,2}$ The lawsuit was brought by Texas et al as plaintiffs vs California et al as defendants. The case was filed in February of 2018 by plaintiffs who included 18 Republican state attorneys general and two Republican governors. The defendants included 16 Democrat state attorneys general. In June of 2018 the Department of Justice declined to defend the case. The defendants plan to appeal the decision. The case will likely be heard by a federal appeals court and will possibly be heard by the Supreme Court of the United States (SCOTUS).

Judge O'Connor's ruling was based on the text of the ACA, a previous Supreme Court challenge to ACA: National Federation of Independent Businesses vs. Sebelius (NFIB), and the Tax Cuts and Jobs Act of 2017 (TCJA). The logic of the ruling starts by stating that the Individual Mandate was essential to the proper function of ACA. "Finally, Congress stated many times unequivocally-through enacted text signed by the President-that the Individual Mandate is 'essential' to the ACA. And this essentiality, the ACA's text makes clear, means the mandate must work 'together with the other provisions' for the Act to function as intended. All nine Justices to review the ACA acknowledged this text and Congress's manifest intent to establish the Individual Mandate as the ACA's essential' provision. The current and previous Administrations have recognized that, too." ${ }^{2}$ The ruling on NFIB by SCOTUS found that the Individual Mandate was an unconstitutional exercise of the Interstate Commerce clause, but that it could be constitutionally interpreted as a tax on those who decided not to purchase health care insurance.

Corresponding author: Gilbert Berdine

Contact Information: Gilbert.Berdine@ttuhsc.edu
"In NFIB, the Supreme Court held the Individual Mandate was unconstitutional under the Interstate Commerce Clause but could fairly be read as an exercise of Congress's Tax Power because it triggered a tax."2 This ruling was very controversial, but rulings by SCOTUS have no higher appeal. As Judge O'Connor noted, however, "The TCJA eliminated that tax. The Supreme Court's reasoning in NFIB-buttressed by other binding precedent and plain text-thus compels the conclusion that the Individual Mandate may no longer be upheld under the Tax Power. And because the Individual Mandate continues to mandate the purchase of health insurance, it remains unsustainable under the Interstate Commerce Clause-as the Supreme Court already held."2

Putting the logical pieces together, Judge O'Connor ruled that the remaining parts of the ACA could not be constitutional without a constitutional Individual Mandate. "Because rewriting the ACA without its 'essential' feature is beyond the power of an Article III court, the Court thus adheres to Congress's textually expressed intent and binding Supreme Court precedent to find the Individual Mandate is inseverable from the ACA's remaining provisions." Judge O'Connor denied the plaintiffs' request for an injunction against the ACA, but the judge granted summary judgement in favor of the plaintiffs. The denial of the injunction means that the ACA will remain in force pending appeal of the decision.

This decision highlights the inherent problem with the ACA: people favor insurance coverage of preexisting medical conditions, but they are opposed to forcing people to purchase insurance. As noted in previous articles, ${ }^{3,4}$ pre-existing conditions are uninsurable and cannot be covered by insurance, so coverage requires some form of subsidy. People favor the subsidy, but do not want to pay for it. President Trump has indicated he does not want to abandon people with pre-existing medical conditions, but he has never acknowledged that coverage would require a subsidy, nor has he articulated a mechanism to pay for this 
subsidy. In these respects, the president is aligned with popular opinion. It remains to be seen how the U.S. government will deal with this conundrum.

Keywords: Affordable Care Act, Individual Mandate, Court ruling

Submitted: $12 / 17 / 2018$

\section{REFERENCES}

1. Texas Judge Rules Affordable Care Act Unconstitutional, But Supporters Vow To Appeal. National Public Radio. https:// www.npr.org/sections/health-shots/2018/12/14/677002085/ texas-judge-rules-affordable-care-act-unconstitutional-butsupporters-vow-to-app. Accessed 12/18/2018.

2. Texas v. United States of America. District Court, N.D. Texas. 2018.

3. Berdine G. The Supreme Court Decision on Obama Care Part 1. The Southwest Respiratory and Critical Care Chronicles. http://www.pulmonarychronicles.com/index.php/pulmonarychronicles/article/view/5/105. Accessed 12/18/2018.

4. Berdine G. Sustainable Health Insurance. The Southwest Respiratory and Critical Care Chronicles. http://www.pulmonarychronicles.com/index.php/pulmonarychronicles/article/ view/488/1056. Accessed 12/18/2018. 